\title{
Early Bananas in Africa: The state of the art
}

Katharina Neumann and Elisabeth Hildebrand

\section{Research}

'...Harlan and De Wet (1973) ... argue that data for early agriculture must be judged by its quality, and that evidence should further be judged by how well it integrates with other data. Evidence that conflicts with wider patterns must be strong.'

Mark Nesbitt (1999)

\section{Introduction}

Because the genus Musa is not indigenous to Africa, remains of bananas in African archaeological or geological contexts indicate cultivation of domesticated forms. During the past 10 years, at least two claims have been made for discovery of banana phytoliths in middle to late Holocene African contexts (Lejju et al. 2005, 2006, Mbida et al. 2000, 2001, 2006). These finds have not met with universal acceptance (cf. Mbida et al. 2005, Vansina 2003), in part because application of phytolith studies to African archaeology is just beginning. In this paper, we examine current evidence for bananas in Africa, and discuss its implications for African prehistory.

We first consider how various scenarios for the arrival of bananas in Africa relate to broader questions about prehistoric social and economic change. We then explore requirements for archaeological identification of bananas in light of evolutionary, morphological and environmental relations between Musa and its sister taxon Ensete, which grows wild in Africa. Finally, we evaluate existing evidence for Musa in prehistoric African contexts and suggest ways in which future research might help consolidate current claims.

\section{Potential significance of banana discoveries}

Evidence for early banana cultivation in Africa pertains to four major questions in African prehistory: the timing of first Africa/Asia contact; the nature of contact and exchange between coastal areas and central portions of the continent; the relative antiquity of indigenous vs. exotic crops in Africa; and the role of banana cultivation in the prehistoric spread of Bantu-speaking farmers.

\section{The entry of bananas: Contact with Asia}

Contact between Africa and Asia fueled an exchange of crops, but the timing and nature of these transfers of plants and technology are murky. Sorghum, a crop indigenous to Africa, appeared in South Asia earlier than current archaeological evidence for its domestication in Africa (Fuller 2003). Moving in the opposite direction, the introduction of bananas to Africa is not well understood, although two primary scenarios have been proposed. The first entails introduction in several waves via the In-

\section{Correspondence}

Katharina Neumann, Institute of Archaeological Sciences, Goethe University, Frankfurt am Main, GERMANY.

k.neumann@em.uni-frankfurt.de

Elisabeth Hildebrand, Department of Anthropology, Stony Brook University, Stony Brook, NY, U.S.A.

ehildebrand@notes.cc.sunysb.edu

Ethnobotany Research \& Applications 7:353-362 (2009)

Published: July 30, 2009 
dian Ocean, starting more than 2000-3000 years ago (De Langhe et al. 1994/95, De Langhe \& de Maret 1999). The second suggests introduction to eastern Africa by people of Malaysian-Indonesian origin, possibly via Madagascar, in the first millennium A.D. (Rossel 1998:220, Simmonds 1966, Smartt \& Simmonds 1995, Vansina 1990:64). Data derived from outside archaeology argue for the earlier scenario: Africa has a strikingly high number of cultivars, among them both $A A B$ plantains cultivated in the Central African rainforest (c. 120 genetically distinct varieties) and AAA bananas in the eastern African highlands (c. 100 varieties). Such high diversity could only have developed through somatic mutation, requiring a long time of cultivation and selection by local farmers (De Langhe et al. 1994/95).

Blench (2009) proposes a third scenario for banana introduction. He argues, based on linguistic evidence, that plantains' first foothold in Africa was not on the Indian Ocean coast. Rather, he suggests that plantains entered western Africa as part of an Indo-Pacific crop package that included taro (Colocasia esculenta (L.) Schott) and water yam (Dioscorea alata L.).

All three of the above scenarios for contact have been derived mainly from linguistic data sets, supplemented in some cases by genetic studies. Firm archaeological evidence is needed to generate a concrete date for early bananas in Africa. This would establish a time frame for early Africa-Asia contact, and therefore the potential exchange of commodities, technology and agricultural knowledge between the two continents.

\section{The spread of bananas: Contact within Africa}

Models for introduction via the eastern African coast entail Musa's spread to distant portions of central Africa. The manner of this spread is enigmatic. How could $A A B$ plantains adapted to continuous humid conditions cross arid regions between the eastern African coast and the central African rainforest? De Langhe (2007) proposes a tentative scenario in which bananas were first adopted and cultivated by non-Bantu populations already practising vegeculture of indigenous African plants around 3000 B.P. Under his scenario semi-agriculturalists, who might have had some knowledge of Ensete cultivation, could have transported the plantains along the humid slopes of the eastern African highlands, eventually reaching Mt Elgon at the eastern edge of the central African rain forest zone. No archaeological remains of Musa, or of other local or exotic cultivated crops, have yet been found in any archaeological site along the proposed route, but this absence of evidence mostly reflects the lack of systematic archaeobotanical sampling and cannot be taken as real evidence of absence.

Blench's model for introduction via the western African coast allows more straightforward scenarios for banana's spread. With the exception of the Dahomey Gap, rainfall variation in western Africa is high near the coast and decreases gradually as one moves north. If established on the coast, banana cultivation could have spread north and east without crossing arid intervening areas. Like the other models, however, this scenario is not yet backed by archaeological data.

\section{The relative antiquity of indigenous vs. exotic crops in sub-Saharan Africa}

The date and location of bananas' entry to Africa, and the speed of their spread across the continent, have implications for the development of regional African agricultural systems. Herding was practiced in many parts of the Sahara by c. 6000 B.C., entered the Sudanese Nile by 5500-3800 B.C., and was known in the West African Sahel by c. 1800 B.C. (Marshall \& Hildebrand 2002). Domestic pearl millet was farmed from Mauretania to Ghana by 1800 B.C. (Kahlheber \& Neumann 2007, Marshall \& Hildebrand 2002, Neumann 2005). Farther east, sorghum and $\mathbf{t}$ 'ef are documented during the first millennium B.C. in Sudan and Ethiopia, respectively, and finger millet by $\mathrm{c}$. 850 A.D. in Kenya (Marshall \& Hildebrand 2002).

According to this sequence, pastoral food production was well established across major portions of the continent long before any proposed dates for banana entry. Chronological relations between African plant domestication and various scenarios of banana introduction are less clear. Because middle Holocene archaeological contexts in eastern Africa have yielded scant plant remains, earlier occurrences of domesticates in this region may yet be found. Still, the early scenario for Musa introduction via the eastern African coast raises the intriguing possibility that some portions of eastern and central Africa saw cultivation of bananas and other Asian crops (e.g., taro, Asian yam, rice) before indigenous African crops.

\section{A potential consequence of banana cultivation: The Bantu expansion}

The introduction and spread of bananas in Africa may also have been key factors in the Bantu expansion, one of the most important topics in African prehistory (Diamond \& Bellwood 2003, Eggert 2005, Vansina 1984, 1995). Vansina (1990) and De Langhe et al. (1994/5) suggest that plantains enabled rapid Bantu colonization of the evergreen rainforest where neither yams nor cereals, adapted to a seasonal climate, could thrive. Blench (2009), in his West African entry scenario, also argues for a key role of Musa, together with the Indo-Pacific crops taro and water yam, in the Bantu expansion.

Understanding Musa's entry and spread across the African continent is thus crucial to several major questions in African archaeology. Until recently, the absence of archaeobotanical data has confined these questions to con- 
jecture. As data finally emerge, growing knowledge of Ensete, the other Musaceae genus indigenous to many parts of Africa, is beginning to raise issues about identification and interpretation of banana finds.

\section{Musa's sister taxon: Ensete}

Musa is indigenous to the southern and southeast Asian tropics, nearby archipelagos and islands in the western Pacific. Its sister genus Ensete is indigenous to the palaeotropics, including Africa. A third genus, Musella, is known from southern China. Together, the three genera constitute the banana family (Musaceae). Ensete has several species indigenous to Africa ( $E$. ventricosum (Welw.) Cheesman, E. gillettii (DeWild.) Cheesman, and E. homblei (Bequaen) Cheesman, Asia and nearby archipelagos (E. superbum Roxb., E. glaucum (Roxb.) Cheesman, E. wilsonii W.J. Tutcher), and Madagascar (E. perrieri (Clavene) Cheesman) (Baker \& Simmonds 1953, Constantine \& Rossel 1999, Liu et al. 2003, Lock 1993, Simmonds 1960).

Discriminating among Musaceae found in African archaeological contexts has multiple implications for the interpretation of palaeoenvironment and prehistoric economy. First, the two genera diverge in environmental preference. Musa plants grow successfully only under constantly high temperatures and in lowland humid conditions with continuous annual rainfall (De Langhe 2007). In contrast, Ensete ventricosum grows $900-2800 \mathrm{~m}$ asl, and spans habitats ranging from wooded grasslands to cool, wet Afromontane environments (Hildebrand 2003), while other African Ensete extend into slightly lower, drier locales, including dry grassland environments. Second, the two genera have different edible parts: Musa has tasty fruits, while Ensete has a massive edible subterranean corm (Hildebrand 2003). Third, Musaceae members also have non-alimentary uses; large leaves are useful for covers or shelter, and leaf sheaths provide fibre for twine (Brandt et al. 1997, De Langhe et al. 1994/95). Finally, Musa could only occur in the African archaeological record in the context of cultivation, while Ensete might occur due to either wild growth or human cultivation.

Given the potential implications of Musaceae finds for paleoenvironmental reconstruction and interpretation of prehistoric economies, secure identification of archaeobotanical materials is crucial. Criteria for identification depend on thorough comparison of modern reference specimens of Musa and Ensete. Here, we review distinctions between the two genera and their applicability to archaeobotanical remains.

The initial generic separation of Ensete and Musa (Cheesman 1947) entailed a few over generalizations but is still regarded as valid (Baker \& Simmonds 1953, Lock 1993, Simmonds 1962). Macroscopic comparisons of the two genera have not yielded results useful for archaeobotany. Well-studied traits differentiating Musa and Ensete plants (Table 1) are unlikely to preserve in archaeological contexts. Manchester and Kress (1993) have noted that Ensete seeds have a pronounced rim around a broad hilar depression; Musa seeds (represented by Musa textilis Née and Musa peekelii Lauterb.) have no such rim, and the hilar depression is not as broad. Unfortunately, seed morphology is of little help in identifying Musa in Africa, or domestic bananas anywhere, due to the prevalence of parthenocarpy (development of fruits without fertilization of the female flower, so that the fruit is seedless yet full of pulp) among domestic forms.

Table 1. Macroscopic traits differentiating Musa and Ensete (Baker 1962, Baker \& Simmonds 1953, Cheesman 1947, Simmonds 1962)

\begin{tabular}{|c|c|c|}
\hline Trait & Musa & Ensete \\
\hline $\begin{array}{l}\text { Production of } \\
\text { suckers/stools }\end{array}$ & Spontaneous & $\begin{array}{l}\text { Not spontaneous: occurs only } \\
\text { if pith damaged through human } \\
\text { or natural intervention }\end{array}$ \\
\hline Flowering & $\begin{array}{l}\text { Occurs many times in life } \\
\text { cycle (due to suckers) }\end{array}$ & Occurs once during life cycle \\
\hline Seeds & $\begin{array}{l}\text { Smaller and numerous (wild) } \\
\text { or tiny (domestic) }\end{array}$ & Hard, $0.8-1 \mathrm{~cm}$ in size \\
\hline Flowers & $\begin{array}{l}\text { Each attached independently; } \\
\text { easily detached }\end{array}$ & $\begin{array}{l}\text { Emerge from pad of tissue integral with } \\
\text { axis; fall off only when tissue rots }\end{array}$ \\
\hline Basal flowers & Usually functionally female & Hermaphrodite \\
\hline Pseudostem base* & Narrow & Swollen \\
\hline Pseudostem shape* & Cylindrical & Pot-bellied \\
\hline Leaf sheaths* & $\begin{array}{l}\text { Tightly encircle the entire } \\
\text { pseudostem circumference }\end{array}$ & $\begin{array}{l}\text { Extend only part way around the } \\
\text { pseudostem, outer leaf sheaths } \\
\text { separate easily from each other }\end{array}$ \\
\hline
\end{tabular}

*Visible by layperson on adult plant. 
Microscopic comparisons suggest differences that could eventually warrant archaeobotanical application, but are not yet fully realized. Manchester and Kress (1993:1267, see also Kress 1990:702) note that pollen grains of Ensete, unlike those of Musa, have 'warty exinous protuberances', but, as none of the recorded plantain cultivars produce pollen (De Langhe pers. comm.), this feature would not help identify plantain cultivation. Starch is a little-explored category of potential evidence; preliminary studies indicate that starch grains from Musa and Ensete can be differentiated (Scott Cummings pers. comm., Lentfer 2009).

A preliminary comparative study assessed diagnostic criteria of African Musa and Ensete leaf phytoliths (Mbida et al. 2001, Vrydaghs et al. 2001). Leaf phytoliths of eight modern Musa cultivars were compared with E. ventricosum and E. gilletii, each represented by one specimen. Among several comparative specimens drawn from Musa cultivars, there was also one AAB plantain. The resulting published drawings showed idealized views of the Musa and Ensete volcaniform morphotype characteristics, but gave neither information about the intrapopulation variability nor quantitative measurements (no scale bar was shown). The significant characteristics included: 1) the morphology of the cone-shaped part, 2) the morphology of the basal portion, 3) the surface of the cone-shaped part, and 4) the morphology of the crater rim.

More recent and thorough studies on 28 specimens of wild and domesticated Musa and Ensete (Ball et al. 2006, Vrydaghs et al. 2009) distinguish eight morphological variants present in both genera with variable percentage values. The study of Vrydaghs et al. (2009) shows that the shape of the volcaniform cone is not a reliable differentiation criterion, as convex and concave cones are present both in Ensete and Musa. The three other differentiating morphological characteristics used by Mbida et al. (2000, 2001) are not considered in Vrydaghs et al. (2009). Vrydaghs et al. (2009) propose the mean crater width on top of the cone to be a differentiating characteristic, which is significantly smaller in Ensete than in Musa.

\section{Current archaeobotanical evidence: The state of the art}

Hard evidence for prehistoric banana cultivation in Africa, in the form of micro- or macrobotanical crop remains, currently remains very sparse. This 'dearth of data and surfeit of models' (Gautier 1987) is due to a lack of systematic archaeobotanical sampling in most African archaeological excavations. Because archaeobotanical data have become available only very recently, any crop remains found in the Central African rainforest and dated to the first millennium B.C. or earlier are highly significant.

Thus, two papers claiming the presence of banana phytoliths in pits at Nkang in the southern Cameroonian rain- forest between 800 and 400 cal B.C. (Mbida et al. 2000, 2001, and Mbida et al. 2006, summarizing the two original publications), received intense interest and controversial response (Vansina 2003, Mbida et al. 2004, 2005). Musa phytoliths were also reported from levels dated to the 4th millennium B.C. in a geological trench at Munsa swamp in Uganda (Lejju et al. 2005, 2006).

Each of these studies has potential to reshape views of later African prehistory in significant ways. The Nkang finds could support the earlier of the two classic scenarios for banana introduction to Africa, or substantiate Blench's model for introduction via the western African coast. The Munsa finds could establish bananas as the first domestic plants in Africa outside of the Nile Valley, force drastic revisions in timetables for contact with Asia, and imply thousands of years of banana cultivation in eastern or central Africa before local domestication or adoption of other African crops.

Given these far-reaching potential implications, a critical review of the evidence is in order (Table 2). We apply the criteria of the classic paper by Harlan \& De Wet (1973), in which they argue that data for early agriculture must be judged by both their quality and their degree of integration with other data sets. Harlan \& De Wet set forth five criteria for determining the reliability of archaeobotanical data:

1. authenticity (identification, archaeological context, dating);

2. abundance (1000 phytoliths have a higher degree of confidence than one or two);

3. kind of evidence (primary or circumstantial);

4. interpretation (likelihood of hypotheses); and,

5. integration with other sources of information.

Questions regarding Harlan \& De Wet's first criterion, 'authenticity,' relate mainly to identification. As described above, recent studies of modern Musa and Ensete phytoliths shed new light on standards for identification and spur re-examination of claims for Musa at Nkang and Munsa. At both sites, original criteria for separating Musa and Ensete volcaniform phytoliths included the shape of the cone, the surface of the cone-shaped part, and the morphology of the crater rim and basal portion. Given that the shape of the cone can no longer be regarded as reliable (Vrydaghs et al. 2009), the identification of the Nkang phytoliths as Musa must be regarded as preliminary. The validity of Mbida et al.'s other identification characteristics cannot be assessed at present, as they are not considered within Vrydaghs et al.'s new study. However, figures 3-6 in Mbida et al. (2001) and figures 6.6-6.8 in Mbida et al. (2006) clearly show phytoliths identified as Musaceae. Their identification to the genus Musa should be rechecked using the new comparative criteria advanced by Vrydaghs et al. (2009).

Vrydaghs et al.'s new criteria also may be applied to check identifications of the Munsa phytoliths. The phyto- 
Table 2. Review of phytolith evidence for early African banana cultivation, applying the criteria of Harlan \& De Wet (1973).

\begin{tabular}{|c|c|c|}
\hline Major criterion & \multirow{2}{*}{$\begin{array}{l}\text { Nkang, southern Cameroon } \\
\text { (Mbida et al. 2000, 2001) }\end{array}$} & \multirow[t]{2}{*}{ Munsa, Uganda (Lejju et al. 2005, 2006) } \\
\hline Subcriterion & & \\
\hline \multicolumn{3}{|l|}{ 1. Authenticity } \\
\hline Context & $\begin{array}{l}\text { Pits with anthropogenic remains: charcoal, } \\
\text { ceramics, polished stone tools, iron slag, } \\
\text { charred endocarps of Canarium and Elaeis }\end{array}$ & $\begin{array}{l}\text { Swamp site, three sediment cores, only core } \\
\text { M2C3C contains sediments older than } 2000 \\
\text { years }\end{array}$ \\
\hline Evidence & $\begin{array}{l}\text { Musa phytoliths in sediment of pit F9 and } \\
\text { in charred crust of ceramic sherd from pit } \\
\text { F7NF }\end{array}$ & $\begin{array}{l}\text { Phytoliths identified as Musa together with Ensete } \\
\text { and Musaceae undifferentiated in lower part of } \\
\text { core M2C3C; problem of differentiating Musa from } \\
\text { Ensete when both can be expected }\end{array}$ \\
\hline Identification & $\begin{array}{l}\text { Consistent with stated criteria for } \\
\text { distinguishing Musa and Ensete phytoliths, } \\
\text { but not with criteria of new study by Vrydaghs } \\
\text { et al. (2009) }\end{array}$ & $\begin{array}{l}\text { Phytoliths shown in Lejju et al. 2006:107, Plates } \\
\text { I and J do not seem to be from Musaceae (see } \\
\text { Figure 1). Plate I shows composite globular psilate } \\
\text { phytoliths of unknown origin, Plate J probably } \\
\text { a broken point-shaped phytolith, common in } \\
\text { grasses. Plate F, designated as Musa, might show } \\
\text { a Musaceae phytolith, but crater opening is only } 4 \\
\mu m \text {, much smaller than in modern Musa varieties } \\
\text { (Vrydaghs et al. 2009). }\end{array}$ \\
\hline Documentation & $\begin{array}{l}\text { Four transmitted light microscope photos of } \\
\text { two single phytoliths, one in equatorial, one } \\
\text { in polar view }\end{array}$ & $\begin{array}{l}\text { One SEM photo of identified Ensete, two light } \\
\text { microscope photos of identified Musa from critical } \\
\text { lower part of the core }\end{array}$ \\
\hline Dating & $\begin{array}{l}\text { Eight radiocarbon dates on charcoal from } \\
\text { the site Nkang, three of them for pit F9, } \\
840-370 \text { cal B.C., exact dating hampered by } \\
\text { large plateau of calibration curve; pit F7NF } \\
\text { not dated }\end{array}$ & $\begin{array}{l}\text { Seven radiocarbon dates on core M2C3C; lower } \\
\text { part dated through interpolation of two dates } \\
\text { to } 3200-2000 \text { cal B.C., upper part dated by } \\
\text { interpolation of five dates to } 1000-1700 \text { A.D.; large } \\
\text { hiatus between the upper and lower part }\end{array}$ \\
\hline \multicolumn{3}{|l|}{ 2. Abundance } \\
\hline & $\begin{array}{l}\text { No numbers given. 'The phytoliths could be } \\
\text { observed in moderate numbers in slides ...' } \\
\text { (Mbida et al. 2001) }\end{array}$ & $\begin{array}{l}\text { Fourteen Musaceae-type phytoliths in basal } \\
\text { sample, among them eight identified as Musa, } \\
\text { three as Ensete, and the remaining as Musaceae } \\
\text { undifferentiated }\end{array}$ \\
\hline \multicolumn{3}{|l|}{ 3. Kind of evidence } \\
\hline & Primary & Primary \\
\hline \multicolumn{3}{|l|}{ 4. Interpretation } \\
\hline \multirow[t]{2}{*}{ 5. Integration } & $\begin{array}{l}\text { If identification is substantiated and sufficient } \\
\text { abundance is demonstrated, interpretation } \\
\text { of banana cultivation would be justified }\end{array}$ & $\begin{array}{l}\text { Given the unreliable identification, interpretation of } \\
\text { banana cultivation is not justified }\end{array}$ \\
\hline & $\begin{array}{l}\text { Good integration with linguistic and genetic } \\
\text { evidence, but opposite interpretation also } \\
\text { feasible (Vansina 2003). Conflicts with new } \\
\text { evidence from similar archaeological sites } \\
\text { in southern Cameroon, indicating strongly } \\
\text { seasonal climate and cultivation of pearl } \\
\text { millet } 400-200 \text { B.C. }\end{array}$ & $\begin{array}{l}\text { Conflicts with all other data on early crops in Africa. } \\
\text { Up to now, there is no evidence for any form of } \\
\text { agriculture in eastern Africa before } 0 \text { B.C./A.D. }\end{array}$ \\
\hline
\end{tabular}

liths identified as Musa and Ensete from the lower part of the Munsa core $\mathrm{M} 2 \mathrm{C} 3 \mathrm{C}$, dated to c. 3250 cal B.C., are documented by two transmitted light and one SEM photograph (Lejju et al. 2006, p. 107, Plates F, I and J). In comparison with modern and fossil phytoliths from central Africa, currently studied by one of us (K.N.), none of the published photographs appears to depict Musa phytoliths. Plate I, designated as Musa, shows three globular to sub-globular phytoliths in irregular, not linear arrangement, and the typical Musaceae volcaniform cone is not visible (Figure 1A). These composite globular phytoliths (Figure 1B,C) are very common in archaeological sam- 


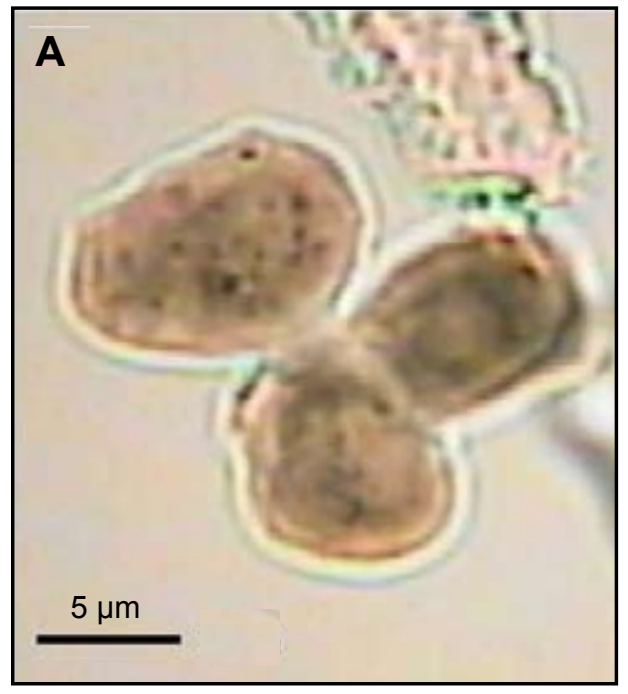

Figure 1. Phytoliths from archaeological sites in Africa and modern reference specimen. Figures $A$ ) and D): Phytoliths from the Munsa core M2C3C, lower part, dated $4560 \pm 40$ B.P. (ca. 3250 cal B.C.), from Lejju et al. (2006): A) Plate I, light micrograph, designated as Musa; D) Plate J, SEM photo, designated as Ensete (courtesy Elsevier). B) light micrograph and C) SEM photo of globular composite phytoliths from archaeological sites in southern Cameroon, dated to 400-200 B.C., origin in plant unknown. E) light micrograph of a modern point-shaped phytolith, common in grasses.
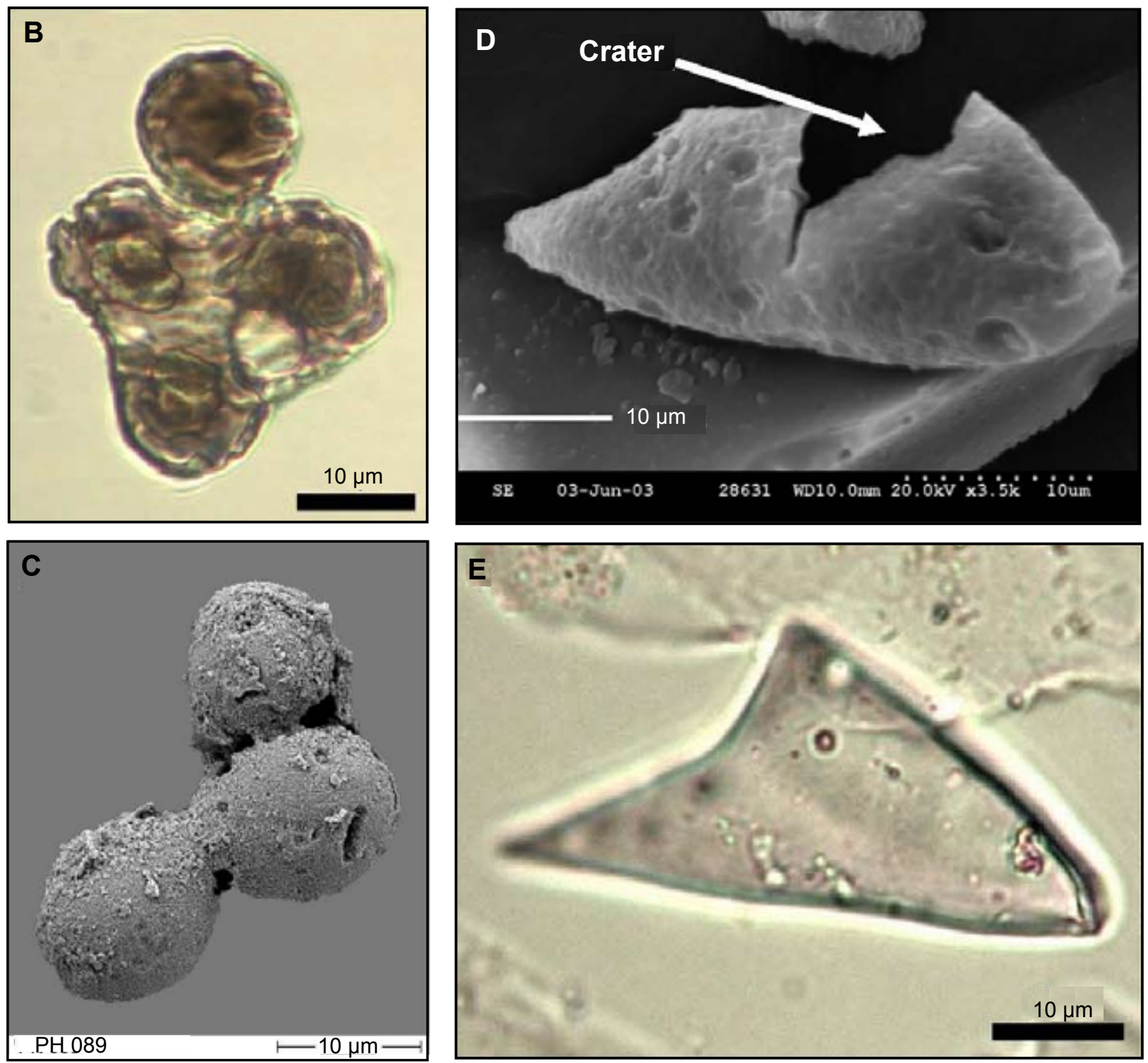

www.ethnobotanyjournal.org/vol7/i1547-3465-07-353.pdf 
ples of southern Cameroon; their origin is unknown, but they surely do not derive from Musaceae, as they lack the typical Musaceae volcaniform shape. Plate $\mathrm{J}$ of Lejju et al. (2006), designated as Ensete, seems to show a broken point-shaped morphotype (Figure 1D), commonly found in grasses (Figure 1E). Plate F, designated as Musa, is a low resolution light photomicrograph of an ellipsoid body with a crater-like structure. However, the crater opening is c. $4 \mu \mathrm{m}$ wide and would thus not match the criteria of Vrydaghs et al. (2009) for AAB bananas with a mean crater width of c. $7.5 \mu \mathrm{m}$.

Harlan and De Wet's second criterion, 'abundance,' is not met for either the Nkang or Munsa finds. Tables in Mbida et al. $(2000,2001,2006)$ present no quantitative information on archaeological phytoliths from Nkang. From the critical basal part of the Munsa core M2C3C Lejju et al. (2005:1057) identified 14 Musaceae-type phytoliths; of these, eight are attributed to Musa, three to Ensete and three to undifferentiated Musaceae. Given the unreliable identification at Munsa, the numbers of Musa phytoliths are also questionable.

We now turn to Harlan \& De Wet's fifth criterion, 'integration with other data sets.' The Nkang finds' adherence to this standard merits serious consideration on two grounds. First, recent phytolith studies on first millennium B.C. sites from southern Cameroon, archaeologically comparable with Nkang, have as yet not yielded any banana phytoliths (Eggert et al. 2006, Höhn et al. 2007, Kahlheber et al. in press a). Second, the presence of banana phytoliths at Nkang might be inconsistent with local paleoenvironmental sequences. A climatic crisis between 400 and 200 cal B.C. caused pronounced seasonal variation in rainfall (Ngomanda et al. 2009). The resulting partial breakdown of the central African rainforest enabled cultivation of the savanna crop Pennisetum glaucum (L.) R. Br., notable for its growth under dry conditions (Eggert et al. 2006, Kahlheber et al. in press $a, b)$. The precision of the dating of Nkang is compromised by the large plateau of the calibration curve. With a range of 850 cal B.C. - 1 cal A.D. (Mbida et al. 2000), Nkang might either be older or contemporaneous with the sites Abang Minko'o and Bwambé Sommet where Pennisetum was found. If Nkang should turn out to be older than Bwambé Sommet and Abang Minko'o and fall into the period before 500 cal B.C. with stable climatic conditions (Ngomanda et al. 2009), plantain cultivation could be conceivable. If the three sites are contemporaneous, however, the distinct dry seasons allowing cultivation of $P$. glaucum would have prevented local cultivation of plantains, which require constant humidity.

Scant archaeobotanical data from eastern Africa in the $4^{\text {th }}$ millennium B.C. make it difficult to evaluate the Munsa finds' integration with nearby sites. Larger integrative issues are clear; the presence of bananas in Uganda in the $4^{\text {th }}$ millennium B.C. would require contact with Asia by that time. Such contact would surely have resulted in the ex- change of a wide range of goods, and exchange of agricultural knowledge and seed stock beyond the transfer of some banana shoots. At present, we lack archaeological evidence for such contact in Later Stone Age and/or Pastoral Neolithic sites across Kenya. This does not preclude the existence of such contact, of course, and archaeologists working between Munsa and the coast should seriously consider this possibility, comb existing assemblages and data sets for possible evidence of contact, and initiate new research to construct a regional framework for establishing dates of early contact with Asia. However, at present no evidence of contact bolsters the Munsa finds.

Summarizing the data review, the identification of the finds from Nkang as belonging to Musa must be regarded as preliminary. The Munsa M2C3C phytoliths, as documented in the two publications of Lejju et al. (2005, 2006), do not seem to be from Musa, and even their status as Musaceae is doubtful. Both sites urgently need further botanical re-assessment.

\section{An agenda for future research}

Given the great potential significance of Musa finds for African archaeology, we hope researchers will continue active pursuit of the banana question. To resolve current ambiguities, we recommend the following directions for phytolith research:

- Detailed studies on modern African Ensete and Musa leaf phytoliths, with stronger representation of central African AAB Musa, eastern African AAA Musa and Ensete among comparative specimens;

- Quantitative phytolith studies on a representative number of Central African rainforest sites from the first millennium B.C. onwards; and,

- Systematic sampling for phytoliths in archaeological sites along the potential plantain dispersal route (as posited by De Langhe 2007).

Other promising avenues lie outside of the phytolith field. Detailed comparisons of Musa and Ensete starch could provide a separate line of evidence for tracing banana's spread. More frequent sampling for macrobotanical remains at eastern African sites after 4000 B.C. would generate entry dates for other Asian crops, and build a wellintegrated picture of pathways to food production for this region. Finally, more durable lines of evidence for contact with Asia could do much to resolve this debate. For this, we must enlist archaeologists studying diverse forms of middle and late Holocene material culture in eastern Africa to help build a broader integrative framework for assessing evidence for early banana cultivation. 


\section{Acknowledgements}

Our collaboration was made possible by a fellowship from the Alexander Humboldt Foundation to Hildebrand for research at the University of Frankfurt. We are grateful to Katheryn Twiss for kindly reviewing a draft of this manuscript, and to Monika Heckner for artwork assistance. The manuscript was greatly improved by critical comments and suggestions of Tim Denham, Luc Vrydaghs and Edmond De Langhe. However, the authors are fully responsible for any shortcomings in the text.

\section{Literature Cited}

Baker, R. \& N.W. Simmonds. 1953. The genus Ensete in Africa. Kew Bulletin 8:405-416.

Ball, T., L. Vrydaghs, I. Van den Hauwe, J. Manwaring \& E. De Langhe. 2006. Differentiating banana phytoliths: Wild and edible Musa acuminata and Musa balbisiana. Journal of Archaeological Science 33:1228-1236.

Blench, R. 2009. Bananas and plantains in Africa: Re-interpreting the linguistic evidence. Ethnobotany Research and Applications 7:363-380.

Brandt, S.A., A. Spring, C. Hiebsch, J.T. McCabe, E. Tabogie, M. Diro, G. Wolde-Michael, G. Yntiso, M. Shigeta \& S. Tesfaye. 1997. The Tree Against Hunger: Enset-based agricultural systems in Ethiopia. American Association for the Advancement of Science, Washington, DC with Awassa Agricultural Research Center, Ethiopia, Kyoto University Center for African Area Studies, Japan, and University of Florida, Gainesville. www.aaas.org/international/africa/ enset/index.shtml

Cheesman, E.E. 1947. The classification of the bananas. Kew Bulletin 2:97-117.

Constantine, D. \& G. Rossel. 1999. The Musaceae: An annotated list of the species of Ensete, Musa, and Musella. www.users.globalnet.co.uk/ drc/

De Langhe, E.R. Swennen \& D. Vuylsteke. 1994/95. Plantain in the early Bantu world. Pp. 147-160 in The Growth of Farming Communities in Africa from the Equator Southwards. Edited by J.E.G.Sutton. Azania 29/30, British Institute in Eastern Africa, Nairobi.

De Langhe, E. \& P. de Maret. 1999. Tracking the banana: Its significance in early agriculture. Pp. 377-396 in The Prehistory of Food: Appetites for change. Edited by C. Gosden \& J. Hather. Routledge, London.

De Langhe, E. 2007. The establishment of traditional plantain cultivation in the African rain forest: A working hypothesis. Pp. 361-370 in Rethinking Agriculture. Archaeo- logical and ethnoarchaeological perspectives. Edited by T. Denham, J. Iriarte \& L. Vrydaghs. One World Archaeology 51. Left Coast Press, Walnut Creek.

Diamond, J. \& P. Bellwood. 2003. Farmers and their languages: The first expansion. Science 300:597-603.

Eggert, M.K.H. 2005. The Bantu problem and African archaeology. Pp. 301-326 in African Archaeology: A critical introduction. Edited by A.B. Stahl. Blackwell, Oxford.

Eggert, M.K.H., A. Höhn, S. Kahlheber, C. Meister, K. Neumann \& A. Schweizer. 2006. Pits, graves and grains: Archaeological and archaeobotanical research in southern Cameroon. Journal of African Archaeology 4:273-298.

Fuller, D. 2003. African crops in prehistoric Southeast Asia: A critical review. Pp. 239-271 in Food, Fuel and Fields. Progress in African archaeobotany. Edited by $\mathrm{K}$. Neumann, A. Butler \& S. Kahlheber. Heinrich-Barth-Institut, Cologne.

Gautier, A. 1987. Prehistoric men and cattle in North Africa: A surfeit of models and a dearth of data. Pp. 163-187 in Prehistory of Arid North Africa. Edited by Angela Close. Southern Methodist University, Dallas.

Harlan, J.R. \& J.M.J. De Wet. 1973. On the quality of evidence for origin and dispersal of cultivated plants. Current Anthropology 14:51-55.

Hildebrand, E. 2003. Enset, Yams, and Honey: Ethnoarchaeological approaches to the origins of horticulture in southwest Ethiopia. Ph.D. dissertation, Department of Anthropology, Washington University in St. Louis.

Höhn, A., S. Kahlheber, K. Neumann \& A. Schweizer. 2007. Settling the rain forest - the environment of farming communities in southern Cameroon during the first millennium B.C.. Pp. 47-59 in Dynamics of Forest Ecosystems in Central Africa During the Holocene. Palaeoecology of Africa 28. Edited by J. Runge. Taylor and Francis, London.

Kahlheber, S. \& K. Neumann, 2007. The development of plant cultivation in semi-arid West Africa. Pp. 318-344 in Rethinking Agriculture. Archaeological and ethnoarchaeological perspectives. Edited by T. Denham, J. Iriarte \& L. Vrydaghs. One World Archaeology 51. Left Coast Press, Walnut Creek.

Kahlheber, S., A. Höhn \& K. Neumann, in press a. Plant use in southern Cameroon between 400 B.C. and 400 AD. In Flora, Past Cultures and Archaeobotany in Africa. Edited by D.Q. Fuller \& M.A. Murray. Left Coast Press, Walnut Creek. 
Kahlheber, S., K. Neumann \& K. Bostoen. in press b. Early plant cultivation in the Central African rain forest: first millennium B.C. pearl millet from South Cameroon. Journal of African Archaeology.

Kress, W.J. 1990. The phylogeny and classification of the Zingiberales. Annals of the Missouri Botanical Garden 77:698-721.

Lejju, J.B., D. Taylor \& P. Robertshaw. 2005. Late-Holocene environmental variability at Munsa archaeological site, Uganda: a multicore, multiproxy approach. The Holocene 15:1044-1061.

Lejju, J.B., P. Robertshaw \& D. Taylor. 2006. Africa's earliest bananas? Journal of Archaeological Science 33:102113.

Lentfer, C.J. 2009. Going bananas in Papua New Guinea: A preliminary study of starch granule morphotypes in Musaceae fruit. Ethnobotany Research and Applications 7:217-238.

Liu, A.-Z., W.J. Kress, \& C.-L. Long. 2003. The ethnobotany of Musella lasiocarpa (Musaceae), an endemic plant of southwest China. Economic Botany 57:279-281.

Lock, J.M. 1993. Musaceae. In Flora of Tropical East Africa. Edited by R.M. Polhill. Balkema, Rotterdam.

Manchester, S.R. \& W.J. Kress. 1993. Fossil bananas (Musaceae): Ensete oregnense sp. nov. from the Eocene of western North America and its phytogeographic significance. American Journal of Botany 80:1264-1272.

Marshall, F. \& E. Hildebrand. 2002. Cattle before crops: The beginnings of food production in Africa. Journal of World Prehistory 16:99-143.

Mbida, C., W. van Neer, H. Doutrelepont \& L. Vrydaghs. 2000. Evidence for banana cultivation and animal husbandry during the first millennium B.C. in the forest of southern Cameroon. Journal of Archaeological Science 27:151-162.

Mbida, C., H. Doutrelepont, L. Vrydaghs, R.L. Swennen, H. Beeckman, E. De Langhe \& P. de Maret. 2001. First archaeological evidence of banana cultivation in central Africa during the third millennium before present. Vegetation History and Archaeobotany 10:1-6.

Mbida, C., H. Doutrelepont, L. Vrydaghs, H. Beeckman, R.J. Swennen, E. De Langhe \& P. de Maret. 2004. Yes, there were bananas in Cameroon more than 2000 years ago. InfoMusa 13,1:40-42.

Mbida, C., H. Doutrelepont, L. Vrydaghs, R.O. Swennen, Ru Swennen, H. Beeckman, E. De Langhe \& P. de Maret.
2005. The initial history of bananas in Africa. A reply to Vansina. Azania 40:128-135.

Mbida, C., E. De Langhe, L. Vrydaghs, H. Doutrelepont, Ro Swennen, W. Van Neer \& P. de Maret. 2006. Phytolith evidence for the early presence of domesticated banana (Musa) in Africa. Pp. 68-81 in Documenting Domestication. New genetic and archaeological paradigms. Edited by M.A. Zeder, D.G. Bradley, E. Emshwiller \& B.D. Smith. University of California Press, Berkeley.

Nesbitt, M. 2002. When and where did domesticated cereals first occur in southwest Asia? Pp. 113-132 in The Dawn of Farming in the Near East. Edited by R.T.J. Cappers \& S. Bottema. Ex Oriente, Berlin.

Neumann, K. 2005. The romance of farming: plant cultivation and domestication in Africa. Pp. 249-275 in African Archaeology. A critical introduction. Edited by A.B. Stahl. Blackwell, Malden.

Ngomanda, A., K. Neumann, A. Schweizer \& J. Maley 2009. Seasonality change and the third millennium BP rainforest crisis in Central Africa. Quaternary Research 71:307-318.

Rossel, G. 1998. Taxonomic-Linguistic Study of Plantain in Africa. CNWS Publications 65. Research School CNWS, Leiden.

Simmonds, J. 1960. Notes on banana taxonomy. Kew Bulletin 14:198-212.

Simmonds, N.W. 1962. The Evolution of the Bananas. Longman, London.

Simmonds, J. 1966. Bananas. Longman, London.

Smartt, J. \& N.W. Simmonds. 1995. Evolution of Crop Plants. 2nd edition. Longman, Harlow.

Vansina, J. 1984. Western Bantu expansion. Journal of African History 25:129-145.

Vansina, J. 1990. Paths in the Rainforests. Toward a history of political tradition in equatorial Africa. University of Wisconsin Press, Madison.

Vansina, J. 1995. New linguistic evidence and 'The Bantu expansion'. Journal of African History 36: 173-195.

Vansina, J. 2003. Bananas in Cameroon c. 500 B.C.E? Not proven. Azania 38:174-176.

Vrydaghs, L., R.O. Swennen, C. Mbida, H. Doutrelepont, E. De Langhe \& P. de Maret. 2001. The banana phytolith as direct marker of early agriculture. A review of the evidence. Pp. 17-185 in Phytolith and Starch Research in 
the Australian-Pacific-Asian regions: The state of the art. Edited by D.M. Hart \& L.A. Wallis. Terra Australis 19. Pandanus Books, Canberra.
Vrydaghs, L., T. Ball, H. Volkaeart, I. van den Houwe, J. Manwaring \& E. De Langhe. 2009. Differentiating the volcaniform phytoliths of bananas: Musa acuminata. Ethnobotany Research and Applications 7:239-246. 